\title{
Internal Branding: An Engine in Building and Sustaining Brand Equity - A Conceptual Paper
}

\author{
Johakim Katekele John \\ Mzumbe University \\ Jerum William Kilumile \\ Mzumbe University
}

Hawa Petro Tundui
Mzumbe University

The 21st century business environment is very dynamic, competitive and complex due to unpredictable changing consumer behaviour, savvy customers, globalization and the impact of technology in general. Organization managers are struggling to think and rethink of the best competitive marketing strategies that can help them to survive in the game. One of the strategies effectively utilized is branding. Organizations are struggling to build appealing, and strong brands that can help to outlive in the game and make profit. Considering that, different strategies employed by managers to invest in building strong brand equity have been promoted in literature; conceptualization of the power of internal branding in building strong brand equity is not clearly established. Therefore, this paper aims at conceptualizing internal branding as an important instrument or strategy that can help an organization to build and sustain brand equity.

Keywords: Brand, Internal Branding, Brand Equity

\section{INTRODUCTION}

Realization of the power of human resource in building and maintaining an organization brand equity has reshaped managers' minds about how properly resources can be allocated in building and sustaining the brand equity. Managers have realized that, building strong brand equity should start from within then outside. Employees have a control power over the success or failure of an organization brand. This means that, to build a strong successful brand requires an organization to have employees who are talented, motivated and committed to deliver the brand promise to the market. Therefore, an organization is required to allocate its resources in the manner that satisfies its employees and make them motivated and committed to live the brand values and reach the brand goals.

It must be remembered that, creating an appealing and strong brand depends on Employees' capability to deliver perceived service quality to the extent of customers' expectation (King \& Grace, 2008). Therefore, creating and maintaining strong and appealing brand requires organization's creativity and effective communication; this role is played by organization's employees. In any organization, brand 
as an asset matters more than any other assets such as machineries, buildings, finance and other tangible assets. This can be evidenced by the resulting statement of the discussion panel at the World Economic Forum in Davos on the success factors of the 21st century that, "People and brand instead of machines" (Butternberg, 2013). Keller (2013) points out that, "the most valuable assets many firms have may not be tangible ones, such as plants, equipment and real estate, but intangible assets such as management skills, marketing, financial, and operations expertise, and most important are brands themselves". Myskova (2011) argues that, "human resources are strategically the most important company resource, even though it cannot be expressed in numbers form a financial point of view". Therefore; it is important for the organization to invest a suitable package in staff development and capacity building to assimilate staffs in to an organization brand(s).

Building a brand is not merely to give a name, symbol, or anything else related to that, but is an art of creating a differential image in targeted customer's mind towards organization's offerings in relation to the organization's competitors (Keller, 2013). This differential image creates the customer perception and shape customer attitude and the general behavior towards the brand. Therefore, to brand is not to create tangible attributes only, the tangible attributes should be supplemented by the intangible elements. In most cases, the employees play a major role in facilitating the tangible attributes through provision of quality customer support, presentation, attending customers, creativity as per customer demand and other brand related services. Therefore the intangible brand image in to customer's mind is largely facilitated by the employees' efforts. Due to this factor, it is imperative to invest in assimilating the employees in to brand values as Keller (2008) argues that, "a strong brand needs a brand driven organization, which can assimilate the brand in to employees".

Mahnert and Torres (2007) argue that, "internal branding reflects the brand value and realizes the brand promise internally and externally". The authors point out that, it is important to assimilate the employees in to the organization's brand(s) because employees always spend their life time working on daily basis with the brand and representing the brand to the external stakeholders. Also Jacobs (2003) presents that a critical factor for organizations to invest in internal branding is that, employees are the ones who determine the company's personality; therefore this means that employees need to live their brand. Keller (2013) emphasizes the critical importance of all employees to have an up-to-date and deep understanding of their organization brand. According to him, internal branding is the best management option in creating and increasing employees' morale and motivation while attracting external targeted customers. Internal branding creates an appealing and more productive work environment (Keller, 2013).

\section{Brand}

Brand is a unique way of an organization to differentiate its products from the products of the competitor (Aaker, 1991). To brand is to give a name, creating a term, sign, symbol, or design or a blend of them where by an organization intend to simplify its product identification in the market and differentiate it from those of competitors' offerings (AMA 1960). Branding involves an art of creating a differential image in target customers' mind towards an organization's products in relation to that of the competitors (Keller, 2013). A registered brand grants an organization with an exclusive patent to be the sole producer, distributer and the seller in the market. Branding simplifies the positioning program simply because the represented product is made totally different from others in the market hence identification and differentiation among the available competing products made simple for the customers. Brand represents the product and communicates the reasons for why consumers should consider consuming the represented product than others in the same category.

\section{Internal Branding}

Internal branding is chiefly concerned with all of the undertakings of the management to assimilate the employees in to the organization brand(s). The aim of internal branding is to enable employees to understand, accept and live the brand values (Mitchell, 2002). It emphasizes the importance of doing internal marketing in realizing the impact of external marketing. King \& Grace (2009) argue that, "marketing has to start from inside out". Internal branding consists of all initiatives that the employer 
undertakes to make the brand and the purpose of the brand well known among the employees. It is a very important practice because it opens up the employee's mind about the brand and enhances the sense of ownership among the employees. Since employees on daily basis work with the brand and represent the brand to the customers and other stakeholders, it is imperative for the employees to be well trained, facilitated and well assimilated in to the brand to ensure the consistence of the brand promises (Baumgarth\& Schmidt, 2010). This perspective implies that employee's service delivery should reflect what is communicated in the promotion mix about the product represented by the brand. Internal branding contributes to employees' self-brand fit, brand knowledge, and belief in the brand (Lohndorf \& Diamantopoulos, 2014). Also internal branding involves employee participation in brand development as Bettencourt (1997) argues that employee participation in brand development is crucial to brand building.

In the paper "The connection between change management and internal branding - Analysis of compatibility of internal branding and John Kotter's 8 steps change process for change" by Scherle, $\mathrm{T}$ et al (2014), the authors analyze the key success factors for internal brand to include the following;

- The nature of organization culture and structure.

- The match between corporate strategy with internal and external brand strategy

- Commitment among employees/staff to understand and support the brand at all levels.

- Knowledge and information about business/operation environment of the organization.

- Education or training of staff and management.

- Management commitment on the success of the internal branding, and;

- An effective communication to ensure consistence in message dissemination.

\section{Brand Equity}

Literatures discuss the term brand equity in to different perspectives. Most of them discus brand equity in two perspectives: the perception perspective or the customer cognitive association perspective, and the financial perspective. Aaker (1991), and Keller $(1993,2002)$ describe brand equity as a set of cognitive association, while Ailawadi et al (2003) and Simon \& Sullivan (1993) describe brand equity as a price or revenue compared to a benchmark competitor and a stock premium respectively. Anderson (2011) presents the 4Ps of brand equity which include the perception perspective, the premium perspective, the portfolio perspective, and the perpetuity perspective. These four perspectives describe brand equity from both customer and financial point of view, that is customer based brand equity (CBBE) and financial based brand equity (FBBE). CBBE means the state of customer response to the marketing activities of the brand due to customers past experience or knowledge about the brand. This can be measured by the cognitive measures such as perceives quality, customer satisfaction and loyalty, brand awareness (Aarker, 1991, Keller 1993, 2002, Jacobson 2008 and Feldwick, 1996) and other customer dimensions as described in the balanced scorecard of 1992. FBBE focuses on financial benefits or value generated from the brand as a result of customer cognitive association. The FBBE can be measured by premium price and revenue premium generated from the brand (Aarker, 1996 and Ailawadi et al, 2003).

Being the focus of this paper is to describe internal branding as an important variable in creating and maintaining brand equity, the paper cannot ignore discussing the concept of Employee Based Brand Equity (EBBE) as one of the aspects of brand equity. EBBE is defined by King \& Grace (2009) as the differential effect that brand knowledge has on employees' response to their work environment. EBBE is easy to be achieved if an organization invests much in internal branding practices that aim at motivating and assimilating the employees in to brand values. EBBE can be measured by looking at employee satisfaction indicators such as retention rate and employee positive word of mouth about the organization (Ramlall, 2004 and Miles \& Mangold, 2004). EBBE helps to achieve the brand dreams both from customer point of view (CBBE) and financial point of view (FBBE). 


\section{Conceptualization}

The idea generation of this paper is based on the assumption that;

H1: Internal branding maximizes Employee-brand assimilation (employee behaviour transformation).

\section{H2: There is a strong relationship between internal branding and brand equity.}

Internal branding brings closer the brand values/promise to the employees and the employees start to live them. During that process employees become part of the brand and work with the strong awareness to achieve the brand objectives. In doing so the brand equity (EBBE, CBBE and FBBE) of the company is built and sustained. From that point of view, investing in internal branding is to create a stock of unique intangible assets which actually the company's competitors cannot have. As presented in the bellow authors' proposed model; the Input-Transformation-Output Model (ITO model), an employer imposes positive actions (Inputs) on to the employees concerning the organization's brand(s) with an intention of changing positively (transformation) the employees' attitudes towards the organization's brand offerings. The positive attitude/behavior towards the brand makes the company realize the positive outcomes which include better performance and strong brand equity (output). This means, to create a strong brand Equity, a Company is first required to build internal brand equity (EBBE).

FIGURE 1

\section{THE POWER OF INTERNAL BRANDING IN BUIDING BRAND EQUITY (INPUT-TRANSFORMATION-OUTPUT-MODEL)}

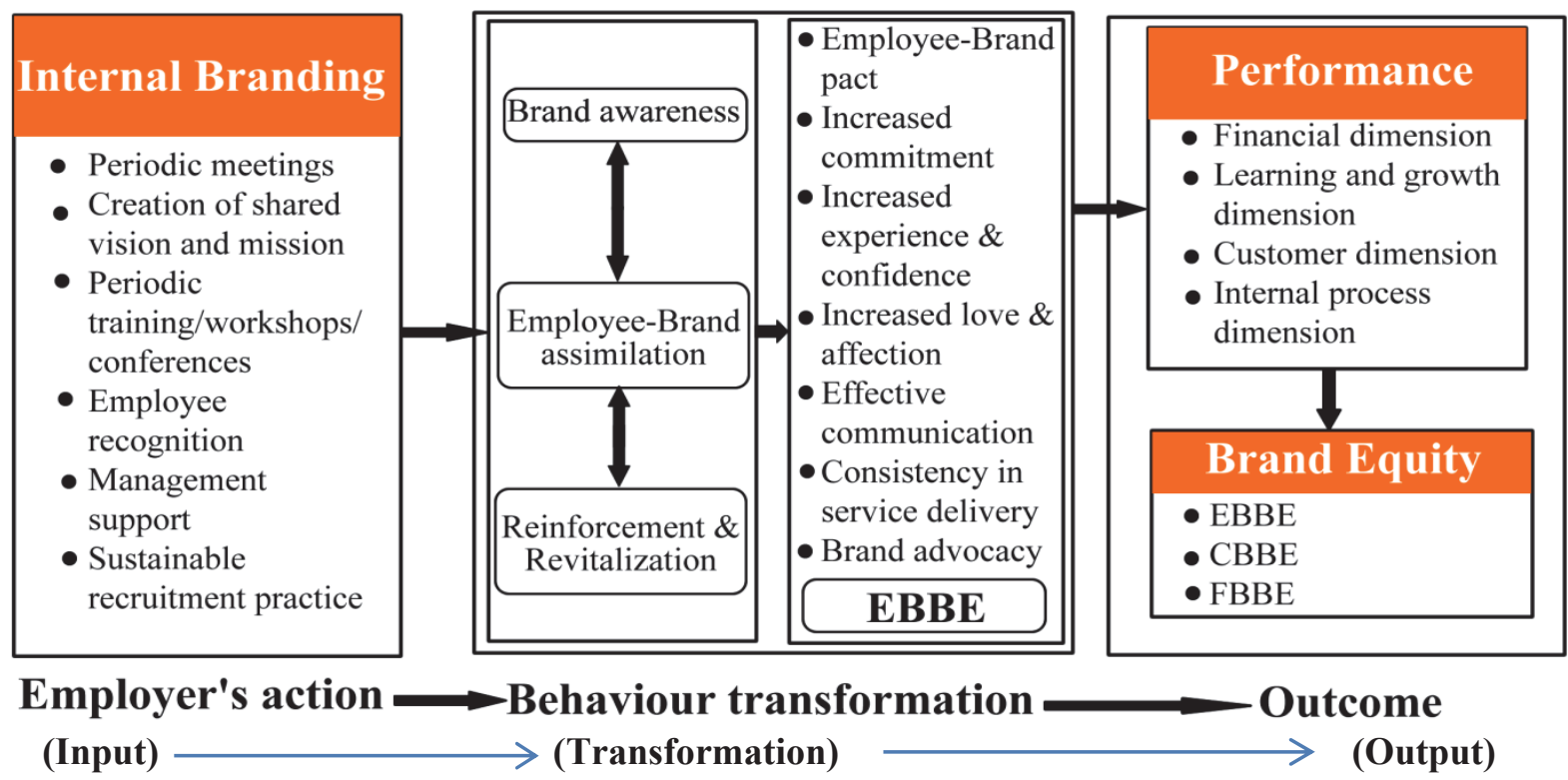

Employer's Action(s) - Inputs

The major success factor for an organization is creating, communicating and maintaining an organization brand, and attracting, developing and maintaining talented and motivated employees (Buttenberg, 2013). To succeed in this, Employers are required to invest a strong package in internal branding. As one of brand equity management strategies, internal branding strategy helps to assimilate the employee in to the brand hence grow and enhance the organization brand equity. Undertakings aiming at revitalizing, reinforcing and creating in-depth awareness of the brand among the employees help to assimilate the employee in to the brand. Training, management support, recognition and rewards, proper orientation, sustainable recruitment practices, and exposure to market related information are the major 
variables that are deemed to help the employees to deliver to the extent of the brand promise (Punjaisri \& Wilson, 2007., McLaverly et al, 2007); hence this makes these variables to be the major employer internal branding actions to be undertaken to transform employees' behavior towards the brand, as also seen in the model.

\section{Employee-Behavior Transformation}

An organization committed to invest in internal branding creates an environment that softens the deliverance of the brand promise. Delivering the brand promise requires employees to be conversant with an organization goals and values; hence this creates the importance of internal branding in the organization. Through internal branding both new and existing employees become motivated and satisfied with the working environment hence employee positive attitude towards an organization. When employee are fully aware of, and understand the brand values they become more committed to the brand (Thomson, 1999). Employees become assimilated in to the brand as a result of in-depth awareness of the brand promise, and periodic reinforcement and revitalization. In this perspective, internal branding assimilates the employees in to the organization brand, and it is through internal branding when an organization gets a chance to reinforce and revitalize the brand values among the employees hence transforming their behavior towards the brand. Internal branding increases employee-brand pact, commitment, love and affection, experience and confidence, consistency in service delivery and more important makes the employees to become the brand advocates and effectively communicate about the brand values. Buttenberg (2013) points out that, better understanding of the brand leads to more brand-consistence behavior and communication hence shapes the employees to be the brand advocates. Internal branding has a positive impact on employees brand support behavior (Boone, 2000). Therefore, it is through internal branding where employees' behaviour transformation towards the brand becomes easier.

\section{Outcome - (Output)}

Internal branding is very important to any organization since it plays a major role of bridging the gap between the brand promise and its delivery (Goom et al, 2008). This means that, an organization performance depends on employees' clear understanding of the purpose of the brand and its values. Internal branding helps an organization to increase and maintain performance because it helps to make an employee motivated, and increases employee commitment, experience and confidence, love and affection. Non-financial and financial performance of an organization is expected to be observed if employees are satisfied by organization's internal branding practices (if the behaviour transformation is positive). Kaplan \& Norton, (1992) present the balanced scorecard which indicates that, performance evaluation should be done by focusing on four aspects, which are; financial aspect, Customer aspect, learning and growth aspect and Internal process aspect. This paper adopt the balanced score card model in describing an organization performance. Any organization which intensively invests in internal branding realizes better performance in those mentioned four dimensions of the balanced scorecard model as also indicated in the proposed ITO model.

Internal branding directly helps to create and sustain Employee Based Brand Equity (EBBE). EBBE is defined by (King \& Grace, 2009) as "the differential effect that brand knowledge has on employees' response to their work environment". EBBE has a great impact in creating and sustaining Customer Based Brand Equity (CBBE). Internal branding plays a major role in employee working environment satisfaction. Employee satisfaction is considered to be a very important dimension of EBBE. When the employees are satisfied, they will not be willing to leave their current organization and will always give positive word of mouth to external stakeholders about an organization brand (Ramlall, 2004., Miles \& Mangold, 2004). Employees' clear understanding of the brand and brand related resources helps the employee to be able to deliver the brand promise (Burmann \& Zeplin, 2005). As indicated in the ITO model, creation of shared vision, periodic training, workshops, and conferences, employee recognition and awards, periodic meetings, proper orientations, management support and sustainable recruitment practices (inputs) leads to employee satisfaction and employee-brand assimilation which results in to EBBE. This satisfaction which leads to EBBE go further steps to shape the employees' attitude towards 
the organization brand (transformation). Due to satisfaction employees increase the general and specific awareness of the brand, increase commitment toward the brand, deep love and affection, employees become more confident and experienced, they become brand advocates to the external market, they maintain consistence in service delivery due to confidence and experience, and finally, communication become more effective both outside and inside of an organization (output). All of these lead to the better performance of the brand both inside and outside the company hence CBBE. Finally, in the presence of $\mathrm{EBBE}$ and $\mathrm{CBBE}$, an organization is expected to enjoy the Financial Based Brand Equity (FBBE) (output).

\section{CONCLUSION}

The proposed model in this paper can help managers to rethink on how to allocate properly the resources in building and sustaining organization's brand equity. Managers should think of internal branding as a competitive strategy rather than just an organization's responsibility. Managers should first struggle to build internal brand equity (EBBE) as a strong foundation for $\mathrm{CBBE}$ and FBBE. Considering that, internal brand equity creates a favorable working environment to the employees and positively reshape employees attitude towards the brand, organization managers should create a proper internal branding model that properly fits with the organization strategic plan.

\section{RECOMMENDATION}

The authors recommend descriptive cross-sectional case study design to be conducted to test the relevance of the assumptions as presented in the proposed ITO model. Other methodologies should be carefully selected to suit the study area, variables and unity of analysis. 


\section{REFERENCES}

Aaker, D. A. (1991). Managing Brand Equity. Free Press, New York

Ailawadi K. L., et al. (2003). Revenue Premium as an Outcome Measure of Brand Equity. Journal of Marketing, 67, 49-64.

American Marketing Association (AMA). (1960). Marketing Definitions: A Glossary of Marketing Terms. AMA, Chicago, IL.

Anderson, J. (2011). Measuring the Financial Value of Brand Equity: The Perpetuity Perspective. Journal of Business Administration Online, 10(1).

Baumgarth, C., \& Schmidt, M. (2010). How Strong is The Business Brand in The Workforce? An Empirical Tested Model of Internal Branding Equity in a Business to Business Setting. Industrial Marketing Management, 39(8), 1250-1260.

Bettencourt. L. A. (1997). Customer Voluntary Performance: Customers as Partners in Service Delivery. Journal of Retailing, 73(3).

Buttenberg, K. (2013). The impact of Employee Branding on Employee Performance. New change of Challenge of Economic and Business Development. University of Latvia.

Feldwick, P. (1996). What is Brand Equity Anyway, and how do You Measure It? Journal of the Market Research Society, 38(2), 85-104.

Jacobs, R. (2003). Turning Employees in To Brand Ambassadors. In ABA Bank Working, 35(3).

Jacobson, R., \& Natalie, M. (2008). The Financial Value Impact of Perpetual Brand Attributes. Journal of Marketing Research, 45.

Lohndorf, B., \& Diamantopoulos, A. (2014). Internal Branding: Social Identity and Social Exchange Perspectives on Turning Employees in to Brand Champions. Journal of Service Research, 17(3).

Keller, K.L. (1993). Conceptualizing, Measuring, and Managing Customer Based Brand Equity. Journal of Marketing, 57, 1-22.

Keller, K.L. (2002). Measuring Outcome of Brand Equity: Capturing Market Performance. Strategic Brand Management. Essex, UK. Prentice Hall.

Keller, K.L. (2013). Strategic Brand Management: Building, Measuring, and Managing brand Equity, 4th ed. Pearson Education Limited: England.

Keller, K.L., et al. (2008). Strategic Brand Management. A European Perspective. Harlow, England and New York. Prentice Hall Financial Time.

King, C., \& Grace, D. (2008). Internal Branding: Exploring the Employees Perspective. Journal of Brand Management, 15(5), 358-372.

King, C., \& Grace, D. (2009). Employee Based Equity: A Third Perspective. Service Marketing Quarterly, 30, 122-147.

Mahner K.F., \& Torres, A.M. (2007). The Brand Inside: The Factors of failure and Success in Internal Branding. In Irish Marketing Review, 19(0.5).

Mitchell, C. (2002). Selling the Brand Inside. In Harvard Business Review, 80(1).

Scherle. T., et al. (2014). The Connection between Change Management and Internal Branding. Analysis of the Compatibility of Internal Branding and John Kotter's 8-step Change Process for change.

Simon, C. J., \& Sullivan, W. M (1993). The Measurement and Determinants of Brand Equity: A Financial Approach. Journal of Marketing Science, 12(1). 